\title{
Production of micronutrient enriched algae, microorganisms and insects for food and feed: Perspectives and updates
}

\author{
Beatriz Felices Rando* and Eldon R. Rene \\ Department of Environmental Engineering and Water Technology, IHE Delft Institute for Water Education, P. O. Box 3015, 2611AX Delft, The Netherlands
}

\begin{abstract}
The high demand of proteins has led to an excessive production of meat, causing many problems such as greenhouse gas emissions and an insufficient supply for the actual protein demand. Although, numerous new sources of proteins have been introduced in the market recently, this has only contributed to the hike in prices of basic food supplies. Thus, researchers and traditional dietricians have found several alternative solutions for meeting the protein requirements, including algae, microorganisms and insects. But there are some issues that need to be overcome before these resources can be completely implemented in the large scale food industry, e.g. health effects, approval from country wise food and agricultural agencies, economical profitability, large scale production and optimization of water requirements, harvesting and downstream processing. This mini-review highlights the perspectives of using algae, microorganisms, enzymes, easily available worms and insects as sources of proteins and ascertains its protein efficiency ratio (PER).
\end{abstract}

\section{Introduction}

In the last few decades, the European Union (EU) has started to be more aware about greenhouse gas emissions and several EU countries are collectively trying to find solutions to solve this persisting issue. In the emerging topic of food - energy - climate change nexus, it is known that the main source of these greenhouse gas emissions comes from meat production and various (intensive) agricultural activities. Currently, nearly a $40 \%$ of the proteins consumed by humans comes from animals, which not only requires a large water footprint, but it also causes "protein gap»: an insufficient future protein supply as they are usually considered as indispensable macronutrients, that also includes the essential amino acids [1-3]. Therefore, the EU is determined to find alternative sources for proteins, and such new sources so far include (amongst others), algae, microorganisms and insects. An additional application of these novel protein sources can also be found in animal feeding and food for humans [2]. However, according to Almeida et al. [1], the major challenge is the consumption of proteins by humans, at a low-cost and easily availability, and also meeting the socio-economics of a countries population.

\footnotetext{
Algae

Historically, in the eastern world, algae have been traditionally consumed as a vegetable (in soups), while in the western world, they have been widely used for industrial applications. However, in the last few years, the global demand for microalgae and microalgal food is growing and showing a great potential regarding their applications in the food industry [4]. Especially attractive is the content of proteins and micronutrients such as vitamins, calcium, iodine, polyphenols and carotenoids present in microalgae. For instance, some phyllum of algae like red seaweeds contain sufficient levels of proteins that are comparable to those found in high-protein containing vegetables, e.g. soy beans [5]. Nearly $30 \%$ of the current worldwide algal production is
}

sold for animal feeding purposes. Certain types of algae are approved in several countries as for chicken feed and they usually do not require new testing or approval for feed use [3]. Specifically for food applications, Garcia, et al. [6] proposed a simple (only one bead milling step), scalable to the pilot- and industrial scale, mild extraction procedure of functional proteins from green alga Tetraselmis suecica. According to that study, the resulting protein extract contained approximately $50 \%$ (dry weight) of proteins and 26\% carbohydrates, and it also displayed superior surface activity and gelation behavior.

From a biological view point, algae can be divided in microalgae and seaweed; microalgae are single-celled organisms that can grow over a wide range of environmental conditions such as $\mathrm{pH}$, alkalinity, sunlight, the presence of fertilizers and competing ions, whereas seaweeds are complex multicellular organisms growing in salt water or marine environments [3]. Many algal species of seaweeds are harvested from the sea and imported mainly from two countries: Japan and France, although their cultivation is also increasing in other coastal countries. Many of them are used for direct consumption or food supplements, and some others have also been evaluated as feed additives in meal, especially to fish diets.

\section{Microalgae and microorganisms}

In a recent review by Dehghani, et al. (2019) [7], it was mentioned that the protein biosynthesis machinery of some microalgae resembles

${ }^{\star}$ Correspondence to: Rando BF, Department of Environmental Engineering and Water Technology, IHE Delft Institute for Water Education, Westvest 7, P. O. Box 3015, 2611AX Delft, The Netherlands, E-mail: bfe001@un-ihe.org

Key words: novel protein sources, alternative proteins, protein gap, algae, microalgae, edible insects food industry, animal proteins

Received: May 06, 2020; Accepted: May 26, 2020; Published: May 29, 2020 
those of the human and animal cells and the microalgae can assemble fully functional complex proteins that can be safely used in humans. In another report, it was also showed that microalgae can be used as sustainable protein sources for the production of peptide based functional foods for preventing certain types of cardiovascular disease (CVD) [8]. The investigations conducted so far confirm that algal biomass shows promising qualities as a novel source of protein wherein the average quality of most of the algae examined is equal and sometimes even superior in comparison to other conventional plant proteins [2]. Many uses have been made of algal single cell proteins (SCP), including that of human food and animal feed [9].

Algal SCP has mainly been used as dietary supplements, sold as tablets, capsules, powders, and other products available in health/ nutrition/diet themed food stores or nutrition centers and they are often promoted as protein and vitamin supplements or to help people to lose weight [9]. The use of microalgae as animal feed is more recent. A large number of studies have demonstrated the suitability of microalgal biomass as a valuable feed supplement or substitute for conventional protein sources (e.g. soybean meal, fish meal). The target domestic animal is poultry, mainly because the incorporation of algae into poultry rations offers the most promising prospect for their commercial use in animal feeding. Another growing market is the utilization of microalgae in aquaculture. Interestingly, some algal species rich in carotenoids have been used to feed salmon and trout to enhance the color of their flesh $[3,9]$.

In the literatures, special attention has been paid to Spirulina platensis, a multicellular microorganism classified as a green-blue microalga by botanists due to its chlorophyll content. On the other hand, it is also considered as a bacterium by bacteriologists, due to its prokaryotic structure. Spirulina is considered as an excellent food because it is non-toxic, and it offers numerous health benefits to cure anemia, malnutrition and tumor growth, among others. Its value for animal food supplement has also been demonstrated by causing an enhancement of growth acceleration, sexual maturation and increase of fertility in cattle [10]. Figure 1 shows the comparative profiles of amino acid production by different microalgae, together with other conventional protein sources, expressed in g per $100 \mathrm{~g}$ protein [2]. It is evident that the values of Spirulina are comparable and even higher than those of egg.

\section{Insects}

With the increasing demand in alternative protein sources worldwide, insects, a traditional food in several places over the world, have drawn attention of the international community. It represents an innovative food and feed source that is rich in high quality protein, and it also offers other beneficial nutritional ingredients such as fat, minerals and vitamins, depending on the species. It is therefore considered as an outstanding alternative food and feed source and a potential substitute for animal feed [3,11]. Additionally, insect culturing contributes to the recycling of nutrients and it also benefits waste management by using waste material for the growth of insects (e.g. flies grown on or attracted to composting facilities) [12-14].

Some examples of potential insects for application in food in the EU are Gryllodus sigillatus and Acheta domesticus (crickets), Alphitobius diaperinus (lesser mealworm), and Tenebrio molitor (yellow mealworm). Additionally, potential insects for use in feed products in the EU are Hermetia illucens (black soldier fly), larvae of Musca domestica (common housefly), and T. molitor (yellow mealworm) [3].

However, despite the traditional knowledge about insects and their harvesting potential in the wild, the industrial production of safe insect products for human consumption and processing into food and feed should consider chemical and biological hazards related to feed and food production. Typical examples include the following: (i) the insects feed can be contaminated with many toxins when they are cultivated in solid wastes, and (ii) the presence of pathogens, heavy metals that would accumulate in the insect's bodies. Insect safety hazards depend on the insect species and environment; therefore, more attention and research must be directed towards the rearing and harvest conditions of insects destined for food and feed production $[3,11]$. In order to be competitive with the existing (competitively priced) protein sources, insects production in a large scale needs to be increased further, both quantity and quality-wise and at the same time reducing the cost of insect rearing [14].

\section{Protein efficiency ratio (PER)}

In order to be able to summarize and compare the protein value of the reviewed protein sources with the traditional protein sources, some data was collected from the literature. An accurate method to evaluate the quality of proteins is the determination of the protein

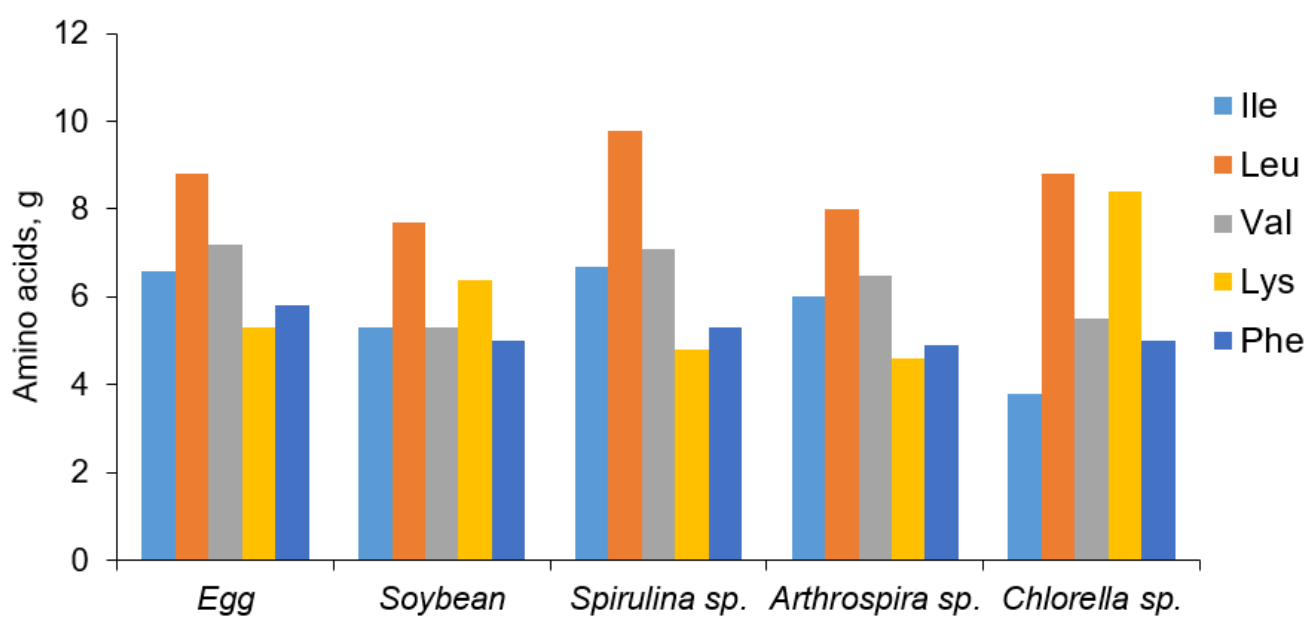

Figure 1. Comparative amino acids profile of different microalgae with conventional protein sources (Becker, 2007) 
Table 1. PER values of different protein sources

\begin{tabular}{|l|l|l|l|}
\hline Product nature/origin & Product & PER & Reference \\
\hline Protein & Casein & 2.5 & {$[15]$} \\
\hline Insect & Variegated Grasshopper $\left(25 \%^{+}\right)$ & 2.37 & 2.1 \\
\hline Microorganism & Spirulina $s p$. & $1.95-2.32$ & {$[14]$} \\
\hline Vegetable & Raw quinoa & $1.2-2.4$ & {$[2]$} \\
\hline Vegetable & Beans, pea flour and soy protein & {$[16]$} & {$[15]$} \\
\hline Animal & Animal proteins & $3.1-3.7$ & {$[15]$} \\
\hline
\end{tabular}

${ }^{+}$The value of PER was calculated through a diet composed of grasshoppers

efficiency ratio (PER), expressed in terms of weight gain per unit of protein consumed by the test animal in short-term feeding trials [2]. In this regard, Table 1 provides information about several products rich in proteins and their respective PER values. The PER value of pure casein protein was considered as the reference $[15,16]$.

\section{Conclusions}

The high demand of proteins and the misuse, abuse and scarcity of traditional protein resources has led to an urgent need of finding novel protein sources. In this regard, researchers and food engineers have shifted their attention to algae, microorganisms and insects as an alternative protein source, as well as for food and feed applications. It has been demonstrated that many of these sources are richer in nutrients, micronutrients and protein content than the traditional sources, and at the same time, they can simultaneously perform environmental bioremediation. Nevertheless, for large scale production, lot of research must be done to overcome problems related to health, economy, technology and social acceptance.

\section{Acknowledgements}

BF Rando thanks IHE Delft (The Netherlands) for providing infrastructural support to carry out this review during Module 6 (Communication Skills for Engineers). The author also thanks the ERASMUS+ IMETE for study and mobility support during the MSc degree program.

\section{References}

1. Almeida SAG, Moreno YMF, Carciofi BAM (2020) Plant proteins as high-quality nutritional source for human diet. Trends Food Sci Tech 97: 170-184.

2. Becker EW (2007) Micro-algae as a source of protein. Biotechnol Adv 25: 207-210.

3. Van der Spiegel M, Noordam MY, Van der Fels Klerx HJ (2013) Safety of novel protein sources (insects, microalgae, seaweed, duckweed, and rapeseed) and legislative aspects for their application in food and feed production. Comp Rev Food Sci Food Safety 12: 662-678.
4. Wells ML, Potin P, Craigie JS, Raven JA, Merchant SS, et al. (2016) Algae as nutritional and functional food sources: revisiting our understanding. J Applied Phycol 29: 949-982.

5. Burtin P (2003) Nutritional value of seaweeds. E J Environ Agri Food Chem. 2: 498503.

6. Garcia ES, van Leeuwen JM, Safi C, Sijtsma L, Eppink MHM, et al. (2018) Selective and energy efficient extraction of functional proteins from microalgae for food applications. Bioresource Technol 268: 197-203.

7. Dehghani J, Adibkia K, Movafeghi A, Maleki-Kakelar H, Saeedi N, et al. (2019) Towards a new avenue for producing therapeutic proteins: Microalgae as a tempting green biofactory. Biotechnol Adv 107499.

8. Ejike CECC, Collins SA, Balasuriya N, Swanson AK, Mason B, et al. (2017) Prospects of microalgae proteins in producing peptide-based functional foods for promoting cardiovascular health. Trends Food Sci Tech 59: 30-36.

9. García-Garibay M, Gómez-Ruiz L, Cruz-Guerrero AE, Bárzana E (2003) Single-Cell Protein | Algae. In: Encyclopedia of Food Sciences and Nutrition (Second Edition), pp: 5269-5276.

10. Sánchez M, Bernal-Castillo J, Rozo C, Rodríguez I (2003) Spirulina (Arthrospira): an edible microorganism: a review. Universitas Scientiarum 8: 7-24.

11. Rumpold BA, Schlüter OK (2013) Potential and challenges of insects as an innovative source for food and feed production. Innov Food Sci Emerging Technol 17: 1-11.

12. Laos F, Semenas L, Labud V (2004) Factors related to the attraction of flies at a biosolids composting facility (Bariloche, Argentina). SSci Total Environ 328, 33-40.

13. Liu T, Awasthi MK, Chen H, Duan Y, Awasthi SK, et al. (2019) Performance of black soldier fly larvae (Diptera: Stratiomyidae) for manure composting and production of cleaner compost. J Environmental Management 251: 109593.

14. Sánchez-Muros MJ, Barroso FG, Manzano-Agugliaro F (2014) Insect meal as renewable source of food for animal feeding: a review. J Cleaner Production 65: 16-27.

15. Gilani GS, Lee N (2003) Protein | Quality. In: Encyclopedia of Food Sciences and Nutrition (Second Edition), pp: 4847-4854.

16. Valencia-Chamorro SA (2003) Quinoa. In: Encyclopedia of Food Science and Nutrition, pp: 4895-4902.

Copyright: (C2020 Rando BF. This is an open-access article distributed under the terms of the Creative Commons Attribution License, which permits unrestricted use, distribution, and reproduction in any medium, provided the original author and source are credited. 